\title{
In memory of Robert Campbell Dalgleish (1940-2009)
}

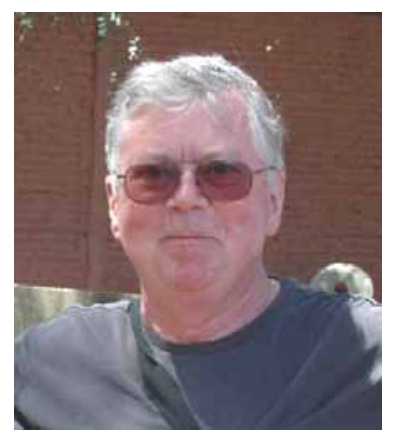

Dr Robert Campbell Dalgleish-Zootaxa's editor for Phthiraptera and Siphonaptera-died suddenly of a heart attack on December 7th at his home in San Diego, California, USA. He was in contact with the editorial office when he accepted two manuscripts for Zootaxa in Nov. 2009 (Lareschi \& Linardi 2009; Mound 2009). I was shocked and deeply saddened when I heard the news of his passing in December 2009.

I first corresponded with Bob in early 2005 when he submitted two papers on Myrsidea for publication in Zootaxa (Dalgleish \& Price 2005; Price, Hellenthal \& Dalgleish 2005). He was very enthusiastic about the new model of Zootaxa. Later, he joined Zootaxa's editorial team in November 2005 as an editor for Phthiraptera. In March 2006, he offered to edit papers on small arthropod (and also some invertebrate) groups without dedicated subject editors (and sometimes manuscripts by subject editors without co-editors for the same group, such as Thysanoptera), and he continued his full support for manuscripts on these taxa until 2008 when he took on editorship for Siphonaptera.

Bob was an excellent and dedicated editor. This is best reflected in what an author-André Nemésio—said to me about him:

"I would like to record that your subject editor, Dr. Robert Dalgleish, is the best editor to whom I have ever submitted a paper. He treated me kindly, honestly, frankly and with absolute correction. Moreover, he was extremely competent and fast in his work. I am very impressed. It's difficult to imagine that ALL editors of Zootaxa are so dedicated as Dr. Dalgleish, but if they present $50 \%$ of his dedication, this journal is in a very firm ground. Congratulations for your choice! Dr. Dalgleish is really what we, authors, expect from every editor!"

Bob was also a very active and important member of the editorial team. He shared his experience with co-editors and gave excellent ideas about how we can improve the standard and service of the journal. In 2007, several editors of Zootaxa organized a symposium ""Zootaxa Phenomena" during the 2007 Annual Meeting of the Entomological Collections Network (ECN). This was held during 8 to 9 December, 2007 in conjunction with the Annual Meeting of the American Entomological Society Meeting, in San Diego, California. Bob gave a presentation "Zootaxa: Phthiraptera" and took the time and effort to prepare a detailed and informative report for me and the editorial team, sharing his reflections and insights:

"Clearly Zootaxa addressed an unmet need. To a certain extent its growth may represent its innovation-will it continue to grow? Consequences of this growth include: increased shelf space in libraries; increased cost to libraries; increased work-load on editors, reviewers, and Zootaxa staff. "Burn-out" was an oft used expression of concern by presenters. Now that other journals are adopting some of Zootaxa's practices, competition for authors will increase. It appeared to be the consensus that the increase in Zootaxa publications was not at the expense of other journals, though I presented evidence (a few authors) who had dropped their membership in societies and no longer published in these journals. Other journals are coming online with no page costs, with Open Access (OA) and meeting ICZN publication/distribution requirements. I spoke in regards to the need for Zootaxa to evaluate its hardcopy production, possibly adopting a ICZN Code compliant distribution at a much lower cost. Will these new taxonomically oriented online journals erode Zootaxa's growth was not openly discussed, but I suspect was on the mind of many.

That Zootaxa was a topic of this ECN meeting underscores its importance to insect taxonomists. The quality of the publication was highly regarded and its continued success is in the best interest of insect taxonomists and others. Thus the discussions were presented in a constructive context." 
In 2008, I started a cybercommunity for zoological taxonomists (http://www.zootaxa.info) with the help of EDIT to facilitate communication among authors/editors/editors of Zootaxa. Bob offered his support as Managing Editor for the site and shared his experience running a similar site hosted by EDIT for Phthiraptera (http://www.Phthiraptera.org). When we started to discuss the possibility for an international society, he offered his advice and support and shared his experience being a founding member of the Organization of Biological Field Stations (OBFS) and National Association of Marine Laboratories (NAML) in the USA.

It is with regret that I never met Bob in person. My knowledge of him is from his CV, his correspondence to me, and a short article on some aspects of his life and career and major contributions that Vince Smith posted on 31 Dec. 2009 on his website ${ }^{1}$. In one of Bob's letters in 2007, he wrote about his career after graduation from Cornell University:

"I was encouraged by Theresa Clay to get into the field and observe lice on their hosts. Thus I spent the next thirty years collecting, not publishing anything. Now that I have retired from university administration I can devote my efforts to describing the chewing lice I observed and collected. In that they are rather host specific it is imperative that one also know a bit about the biology of the avian or mammal host. I find myself devoting as much effort to verifying the host as I do the describing of the louse."

He listed nine refereed papers in his CV (prepared in 2004)2, with five published between 1966 and 1972 and four during 2002 and 2003. The last few years were certainly the most productive period for him, with eight papers in Zootaxa alone (Dalgleish \& Price 2005; Price, Hellenthal \& Dalgleish 2005; Price \& Dalgleish 2006; Palma, Dalgleish \& Price 2007; Price \& Dalgleish 2007; Price, Johnson \& Dalgleish 2008a,b.c). Despite the relatively short list of publications, Bob will be remembered as an excellent editor, a central figure in the Phthiraptera (louse) research community, and a leader/organizer of international efforts to promote research on lice and taxonomy (Smith 2009).

Bob's mentor Theresa Clay once offered her depressing assessment of the profession: "Taxonomy is a fools game, and the fools are winning!". His response was more positive: "There are times when I agree with her, but I like the challenge and the fools keep me entertained." He enjoyed his passion for Phthiraptera and taxonomy until the last minute of his life, when he was found at his desk surrounded by his specimens and literature, and next to his computer (Smith 2009).

\section{References}

Dalgleish, R.C. \& Price, R.D. (2005) Two new species of the genus Myrsidea Waterston (Phthiraptera: Menoponidae) from cotingas (Passeriformes: Cotingidae). Zootaxa, 983, 1-6.

Lareschi, M. \& Linardi, P.M. (2009) Morphological variability in Polygenis (Polygenis) platensis (Jordan \& Rothschild) (Siphonaptera: Rhopalopsyllidae: Rhopalopsyllinae) and taxonomic consequences. Zootaxa, 2310, 35-42.

Mound, L.A. (2009) New taxa and new records of Australian Panchaetothripinae (Thysanoptera, Thripidae). Zootaxa, 2292, 25-33.

Palma, R.L., Dalgleish, R.C. \& Price, R.D. (2007) Niethammerella Eichler, a senior synonym of Kaysius Price \& Clayton (Phthiraptera: Amblycera: Menoponidae). Zootaxa, 1521, 67-68.

Price, R.D. \& Dalgleish, R.C. (2006) Myrsidea Waterston (Phthiraptera: Menoponidae) from tanagers (Passeriformes: Thraupidae), with descriptions of 18 new species. Zootaxa, 1174, 1-25.

Price, R.D. \& Dalgleish, R.C. (2007) Myrsidea Waterston (Phthiraptera: Menoponidae) from the Emberizidae (Passeriformes), with descriptions of 13 new species. Zootaxa, 1467, 1-18.

Price, R.D., Hellenthal, R.A. \& Dalgleish, R.C. (2005) The genus Myrsidea Waterston (Phthiraptera: Menoponidae) from tyrantflycatchers (Passeriformes: Tyrannidae), with descriptions of 13 new species. Zootaxa, 1048, 1-20.

Price, R.D., Johnson, K.P. \& Dalgleish, R.C. (2008a) Myrsidea Waterston (Phthiraptera: Menoponidae) from wrens (Passeriformes: Troglodytidae), with descriptions of three new species. Zootaxa, 1740, 59-65.

Price, R.D., Johnson, K.P. \& Dalgleish, R.C. (2008b) Five new species of Myrsidea Waterston (Phthiraptera: Menoponidae) from antshrikes and antbirds (Passeriformes: Thamnophilidae). Zootaxa, 1819, 55-62.

Price, R.D., Johnson, K.P. \& Dalgleish, R.C. (2008c) Five new species of Myrsidea Waterston (Phthiraptera: Menoponidae) from saltators and grosbeaks (Passeriformes: Cardinalidae). Zootaxa, 1873, 1-10.

ZHI-QIANG ZHANG

New Zealand Arthropod Collection, Landcare Research, 231 Morrin Road, St. Johns, Auckland 1072, New Zealand zhangz@landcareresearch.co.nz

1. Smith, V. (2009) Robert Campbell Dalgleish (31 March 1940-7 December 2009). Available from http://vsmith.info/Bob-Dalgleish (last accessed on 6 Jan. 2009).

2. http://www.phthiraptera.org/Phthirapterists/dalgleish/dalgleish.htm (last accessed on 6 Jan. 2009). 